\title{
Erratum to: Effect of Metal Ions and Redox Mediators on Decolorization of Synthetic Dyes by Crude Laccase from a Novel White rot Fungus Peniophora
} sp. (NFCCI-2131)

\section{Shiv Shankar • Shikha}

Published online: 11 January 2015

(C) Springer Science+Business Media New York 2015

\section{Erratum to: Appl Biochem Biotechnol (2014) DOI 10.1007/s12010-014-1279-2}

The original version of this article unfortunately contained a mistake. The last name "Nill" of "Shikha Nill" should be removed. The correct name is also provided here.

The online version of the original article can be found at http://dx.doi.org/10.1007/s12010-014-1279-2.

\section{S. Shankar · Shikha $(\bowtie)$}

Department of Environmental Science, Babasaheb Bhimrao Ambedkar University (A Central University), Vidya vihar, Rae bareli Road, Lucknow, Uttar Pradesh 226025, India

e-mail: envscibbau@ymail.com 